\title{
Meeting Basic Needs? Forced Migrants and Welfare
}

\author{
Peter Dwyer* and David Brown** \\ * School of Sociology/Social Policy, University of Leeds \\ E-mail: p.j.dwyer@leeds.ac.uk \\ ** Refugee Council
}

As the number of forced migrants entering Britain has risen, increasingly restrictive immigration and asylum policy has been introduced. Simultaneously, successive governments have sought to limit the welfare entitlements of forced migrants. Drawing on two sets of semi-structured qualitative interviews, with migrants and key respondents providing welfare services, this paper considers the adequacy of welfare provisions in relation to the financial and housing needs of four different groups of forced migrants i.e. refugees, asylum seekers, those with humanitarian protection status and failed asylum seekers/'overstayers.' There is strong evidence to suggest that statutory provisions are failing to meet the basic financial and housing needs of many forced migrants.

\section{Introduction}

An increase in the number of forced migrants entering Britain throughout the 1990s has seen deliberations about the welfare rights of such migrants become the focus of contentious debate. This paper considers welfare rights in relation to the financial and housing needs of four different groups of forced migrants ${ }^{1}$ (i.e. refugees, asylum seekers, those with humanitarian protection status and failed asylum seekers/'overstayers'), resident in the United Kingdom. Following a consideration of the tiering of welfare entitlement that exists for forced migrants in this introduction, the paper is divided into four subsequent sections. The first section provides an overview of relevant legislation. This is followed by a brief outline of relevant background information and the methods and sampling strategy of the Leeds (UK) research that informs the paper. The next two sections then consider the adequacy and extent of the social security and housing provisions available to the four different socio-legal categories of forced migrants interviewed in the Leeds study. Qualitative data generated in the research is used to provide a grounded understanding of forced migration and welfare. The role of formal and informal welfare agencies and actors in meeting needs is explored. It is concluded that the basic housing and social security needs of many forced migrants are not being adequately met. Increasingly forced migrants themselves are providing shelter and day-to-day necessities to those migrants who are denied access to publicly provided benefits and services.

\section{A tiering of entitlement}

The legislative changes of the last decade (see subsequent discussions) have consolidated a long-established link between immigration/residency status and welfare entitlement (Cohen, 2002a; Williams, 1989). This situation is further complicated by the stratified system of entitlement that exists within the generic population of forced migrants 
who enjoy differential eligibility to housing and social benefits, dependent on formal immigration status (CPAG, 2002; Morris, 2002; Sales, 2002; Bloch, 2000). Four basic groups, each with different welfare rights, can be identified.

- Refugees - welfare rights on the same basis as citizens; they enjoy rights to work and family reunion.

- Asylum seekers - those making a claim for refugee status; welfare rights may vary considerably depending on date of entry; those lodging 'in-country claims' more than 72 hours after entry effectively have no right to public support; they are not allowed to work (since July 2002); no rights to family reunion.

- Humanitarian protection/discretionary leave status - (previously known as exceptional leave to remain i.e. ELR), granted for periods of up to three years; the same welfare rights as citizens; they may work, but lack rights to family reunion.

- Failed asylum seekers/'overstayers' - asylum seekers whose claims have been turned down and who have no right to remain and thus no recourse to social welfare or (legal) paid work.

An unknown but substantial number of forced migrants 'disappear' and/or assume other identities. Morris (2002) notes, that in 1998 around 14,000 people received a negative decision but stayed in the UK with no obvious means of supporting themselves. Others (e.g. those in poor health, those who cannot be returned to their country of origin, individuals with a claim under Judicial Review), may be eligible for temporary support from NASS under strictly administered 'hard cases' rules (Refugee Council, 2002b). The combined effect of this tiering of entitlement and successive changes in the law is that different socio-legal categories of forced migrants in the UK have widely different rights to social benefits and housing.

\section{Forced migrants and welfare: a decade of legislation}

As the number of people seeking asylum in the UK has risen, the past decade has seen the introduction of increasingly restrictive immigration and asylum policy (Mynott, 2000, 2002; Sales, 2002). More stringent attempts to keep forced migrants out have been put in place (Blunkett, 2001) and, simultaneously, successive governments have sought to limit the welfare entitlements of asylum seekers who enter the country (Bloch and Schuster, 2002; CPAG, 2002; Morris, 2002). Consecutive pieces of legislation have impacted negatively upon the social security and housing rights of asylum seekers.

Consolidating the approach of their Conservative predecessors the New Labour government introduced the Immigration and Asylum Act (1999). This Act widened the gulf between the social rights enjoyed by UK citizens and those available to asylum seekers. It removed responsibility for meeting asylum seekers' basic social security and housing needs from local authorities and placed it with a new body, the National Asylum Support Service (NASS) that permits people to choose one of two support options: accommodation and subsistence or subsistence only. Rights to social assistance benefits were removed from all persons subject to immigration control and instead certain asylum seekers became entitled to receive vouchers worth 70 per cent of basic income support and $£ 10$ cash. NASS support is, however, highly conditional. Individuals must be destitute, accommodation is offered on a 'no choice' basis and clients have to agree to be dispersed to an allocated cluster area somewhere in the UK. If any of the above, conditions are 
broken, rights to housing and financial support can be withdrawn (CPAG, 2002; Zetter and Pearl, 2000).

The subsequent Nationality, Immigration and Asylum Act (2002) retained the basic framework of NASS support but also initiated important changes in the provision of basic welfare to asylum seekers. In response to widespread condemnation and administrative problems (Eagle et al., 2002; Refugee Council, 2002a; Mynott, 2000), the voucher system was phased out and replaced with 'entitlement cards', which will allow holders to access cash benefits of the same value (Refugee Council, 2002c; Sales, 2002). Most controversially Section 55 of this Act stated that individuals must apply for asylum status 'as soon as is reasonably practicable' (currently within 72 hours of entering the UK), in order to retain eligibility for NASS provisions. The Act also gave the Home Secretary the power to withdraw or deny NASS support from in-country applicants who fail to co-operate with the authorities. Section 55 which pushed 1000 s of forced migrants into extreme poverty or destitution, has been widely condemned and subject to challenge in the courts (see GLA, 2004; IAP, 2004; Refugee Council, 2004a; Shelter, 2003).

As a result of defeat for the government in the Court of Appeal, the Home Office suspended the use of Section 55 in May 2004. The policy is under review and the government intends to appeal to the House of Lords (Home Office, 2005). Furthermore, failed asylum seekers/'overstayers' whose claims have been turned down but who remain in the UK will not effected by any changes to Section 55 and continue to run the risk of destitution (Refugee Council, 2004b; Travis, 2004). Since 4 June 2004, the government has also removed the right of NASS supported asylum seekers to apply for the Single Additional Payment (SAP) of $£ 50$. A SAP payment was previously available every six months to help meet the cost of replacing clothing, shoes and other worn out items (CAB, 2004).

The Asylum and Immigration (Treatment of Claimants etc.) Act (2004) has further reduced the welfare rights of forced migrants. New restrictions on eligibility to NASS support for failed asylum seekers/'overstayers' with dependant children have been introduced. The Act places an obligation on adult asylum seekers with young families to accept voluntary repatriation or face the possibility of destitution and their children being taken into care (Home Office, 2003; Refugee Council, 2003; RCC, 2003). Also regulations which previously allowed those granted refugee status to apply for the 30 per cent of Income Support they were denied under NASS rules (back dated from the start of their asylum appeal), have been rescinded.

\section{The Leeds study: background and methodology}

Yorkshire and Humberside has the highest regional population (23 per cent of the UK total), of NASS accommodated asylum seekers (Home Office, 2005). Over 9,000 are housed in the region with the biggest population resident in Leeds (see Table 1). Statistics from the Yorkshire and Humberside Consortium show 2,247 dispersed asylum seekers living in Leeds on 31 October 2004 (Asylum Newsletter, 2005). This figure does not include 'failed asylum seekers' nor the additional 220 Leeds-based forced migrants receiving 'subsistence only' NASS support (Home Office, 2005).

The Yorkshire and Humberside Consortium for Asylum Seekers and Refugees (established in 2000), consists of ten local authorities. As a consortium member Leeds City Council is contracted to NASS to provide 336 properties until October 2005. In June 
Table 1 Number of dispersed asylum seekers in West Yorkshire and Humberside on 31 October 2004

\begin{tabular}{lcc}
\hline \hline Local authority & Housed by local authority & Housed by private sector \\
\hline Barnsley & 372 & 129 \\
Bradford & 308 & 847 \\
Calderdale & 136 & 114 \\
Doncaster & 291 & 539 \\
Hull & 250 & 343 \\
Kirklees & 437 & 518 \\
Leeds & 684 & 1563 \\
Rotherham & 292 & 469 \\
Sheffield & 408 & 980 \\
Wakefield & 302 & 156 \\
TOTALS & 3480 & 5658 \\
\hline \hline
\end{tabular}

Source: Asylum Newsletter March/April 2005.

2003 the council also negotiated a separate contract to provide 65 spaces in the 'Hillside' induction centre for newly dispersed asylum seekers (LCC, 2004). Three other agencies, the Angel Group, Clearsprings (private companies) and Safehaven Yorkshire (a not for profit organisation), are also contracted to supply accommodation for dispersed asylum seekers. These landlords provide the bulk of asylum seekers' accommodation in Leeds, some of which they procure through sub-letting arrangements with other local private landlords (Wilson, 2001).

A range of informal welfare services is also provided by an assortment of charitable and voluntary non-governmental organisations (NGOs) across the city. Many of these are supplied by the key respondents interviewed in the study. In addition a growing number (19) of Refugee Community Organisations (RCOs) (see Table 2), offer various levels of advice, companionship and support. RCOs differ from mainstream NGOs in that they often lack paid staff and are not registered charities. The Leeds-based RCOs organise a range of cultural, social and sporting events and also offer informal legal advice and links to more formal welfare providers to fellow nationals. Three forced migrant respondents interviewed as part of the study ran local RCOs. All three organisations provided interpreting services, informal English classes and helped to place individuals on local college courses. Additionally, one had a particular focus on providing female migrants of African origin with health advice and another was active in taking up failed asylum seekers' cases and instigating appeals on their behalf. Potentially RCOs are a valuable resource which offer forced migrants opportunities for mutual, emotional and practical support.

\section{Method and sampling}

In total 34 respondents took part in the fieldwork. Data were generated in two sets of semi-structured qualitative interviews with 23 forced migrants and 11 key respondents involved in the delivery of welfare services. A purposive non random sampling technique was used and five refugees, seven asylum seekers, six people with subsidiary humanitarian 
Table 2 Refugee community organisations operating in Leeds in September 2004

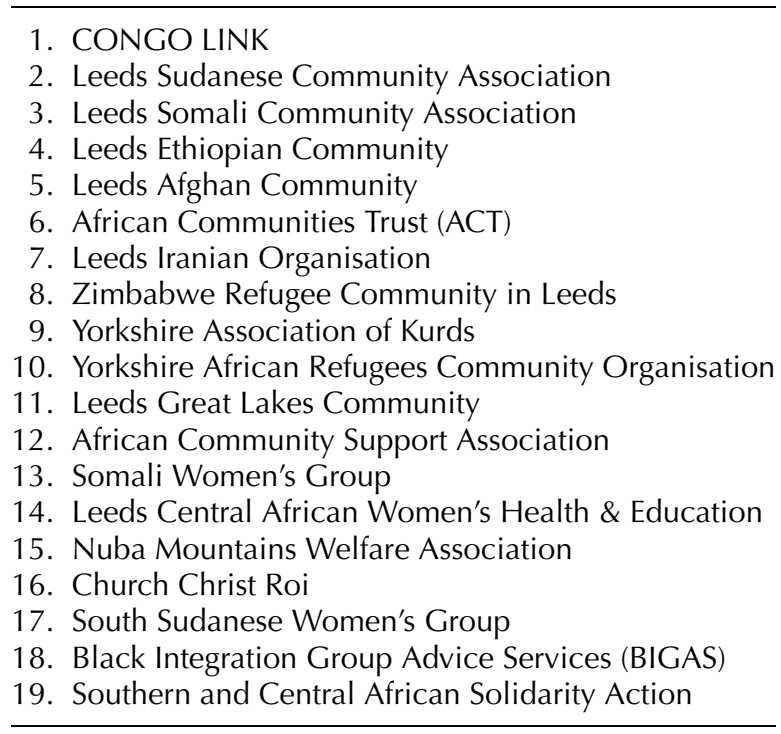

protection status and five failed asylum seekers/'overstayers' were interviewed. As Robinson (2002) and Bloch (2004) note, a singular reliance on RCOs when recruiting respondents can be problematic in that it may provide access to a particular, and limited, population of respondents. Accordingly, in order to increase the diversity of the sample and extend the study's reach, a number of tactics were used to recruit forced migrants. Some were referred to us by key respondents, others replied to leaflets that we distributed at various drop-in centres across the city and others responded to personal requests from the researcher who regularly visited appropriate locations. Thirteen of the forced migrants were male and ten were female. Ages ranged between 21 and 57 years. Migrants identified nine countries of origin; Afghanistan, Democratic Republic of Congo, Iran, Iraq, Iraqi Kurdistan, Kosovo, Pakistan, Somalia and Zimbabwe. ${ }^{2}$

Interviews were conducted in Leeds between 30 January 2004 and 21 June 2004 and lasted on average 60 minutes. Two ethical principles underpinned the fieldwork: informed consent and confidentiality. Forced migrants who participated each received a $£ 20$ supermarket voucher. All migrants were offered the use of a suitable interpreter but the majority (18) chose to be interviewed in English. Interviews were recorded on audiotape and transcribed verbatim. Subsequent transcripts were anonymised, assigned a code number (e.g. FM1, KR2) and analysed using grid analysis and thematic coding techniques (Ritchie et al., 2003; Mason, 2002). A Nudist 6 computer software package was used to assist this process.

\section{The inadequacy of financial provision}

Against the complex backdrop of formal and informal welfare provisions that may or may not be available to forced migrants, depending on their socio-legal status and location 
within the UK, a key aim of the Leeds-based study was to explore the extent to which forced migrants' basic day-to-day financial and housing needs are being met. Interviews indicated that many migrants routinely experience poverty and social exclusion. The clear view of the overwhelming majority (20) of forced migrants was that, for those with rights to social benefits, welfare had been reduced to little more than subsistence level. Those without rights were literally counting pennies.

For eating its ok, but not for clothing, not for other things. Its just to survive. (FM10 asylum seeker)

Sometimes you can't even afford to eat. The 23 pennies to buy a loaf of Tesco bread, its not every day, but sometimes you won't even get that money. (FM5 failed asylum seeker/'overstayer')

Vincent has argued that the 'defining characteristic' of living in poverty is when 'the attainment of any one basic goal always involve(s) the loss of another' (1991: 4). For many, making ends meet was a constant worry.

We used to walk to the town centre because its $£ 1.20 \ldots$ That's like $£ 2.40$ [for two] so we're thinking ok we can buy three cans of those kidney beans or something so that we can eat for two days. (FM19 asylum seeker)

Sometimes when I need a bus pass to come to the city centre to go to church I can't afford it ... If I need to buy some clothes, I can't afford to pay for shoes. (FM17 ELR)

\section{Socio-legal status and social security}

As previously noted, the specific benefit rights of forced migrants are linked to their socio-legal status. At risk of stating the obvious, failed asylum seekers/'overstayers' were the most disadvantaged group in the study. Given earlier discussions it may initially seem contradictory to report that all of the failed asylum seekers/'overstayers' we interviewed talked in terms of at least managing to get by at a basic level when they previously enjoyed rights to NASS support. However, such sentiments reflect their current plight (i.e. a situation in which they are devoid of any rights to welfare), rather than the adequacy of NASS provision. A destitute, failed asylum seeker even appeared to be almost nostalgic about a time when their previous status of 'asylum seeker' afforded them basic accommodation and limited financial support.

What I can say is at first it was good since we were living in a supported house and everything was well. We were living in a nice way and getting our money from the post office. But when it came to the end of the tribunal, we were told to move out of the house, that's when the problems started. (FM6 failed asylum seeker/'overstayer')

Another respondent, with ELR status who had originally arrived in Leeds in 1999 as part of a government managed and endorsed refugee programme outlined the benefits of their initial, relatively privileged, entry status.

I felt most welcome, I was just baffled basically. I wasn't expecting such a welcome, it was everything medical provision, food, clothes, housing. It was the $* * * * *$ Centre, it was very good. I find it difficult to describe it to you, how good it was. (FM9 ELR)

This is certainly a more positive experience than that endured by other respondents. Within a year, however, any advantages of this particular status had dissipated. Currently this respondent's family survive on a combination of Income Support and Carers Allowance. 
Since leaving the reception centre and being housed in the community the family has faced serious, persistent harassment and violent attack from neighbours.

Those forced migrants who are granted refugee status or leave to remain under humanitarian protection rules are, relatively speaking, better off than asylum seekers and 'overstayers' in terms of their welfare rights. However, two problems remain for these groups. The first is a consequence of the decision to develop a separate welfare system for asylum seekers. The second is a more general issue related to the current levels of social benefits available to poor citizens.

A key informant we interviewed described the 'institutionalising effect' of the separate NASS system of support reserved for asylum seekers.

\begin{abstract}
Its all very nice until you get into the real world where you do have to pay for your own fuel and you have not learnt to pay for your fuel. The fact that you are not allowed to work is another factor. It is actually demoralising and deskilling and the longer they are in the system the more that must be the case... The actual system takes a cushy approach to provision. I wouldn't say it is generous but its cushy in the sense that you don't have to manage your money very much and you don't have to work... If you use the word carefully, there is an institutionalising effect in it because some of the pressures will come upon people whenever they succeed or fail with their asylum claim. (KR10)
\end{abstract}

Our data support the view that NASS provision does not prepare successful asylum seekers for the harsh realties of life at the sharp end of the British social welfare system. The inadequacy of mainstream benefit levels was commented on by five respondents with humanitarian protection or refugee status. One person with ELR talked about running up an electricity bill in excess of $£ 1,000$. Another, stated:

We are very careful with the money so we don't buy extra things. So clothes, food, we don't just go and buy things. We don't buy other things because we can't, it's difficult. (FM3 refugee)

Those who experience a positive change and achieve refugee status become entitled to the same social security benefits as other citizens. In reality the overwhelming majority are gaining the right to apply for limited and increasingly conditional (Dwyer, 2004a, b; 2000) social assistance benefits.

\title{
Destitution
}

Destitution among those forced migrants ineligible for public welfare is an acknowledged problem across the UK (GLA 2004; Refugee Council, 2004a). Increasingly the charitable/voluntary sector and other forced migrants themselves are having to fill gaps in provision. The impact of current policies which deny welfare rights to certain individuals was starkly illustrated by a nurse who worked with forced migrants.

With section 55 we're seeing some people who are not eligible for support when they apply. A couple of weeks ago I had an eight month pregnant woman who was destitute. She couldn't get social services to take her on as a pregnant woman, in relation to the unborn child, and NASS were saying that she'd not applied for support in enough time. So obviously that had massive implications for her. At the other end [there are] destitute people who have come to the end of the process who go home to find their bags on the doorstep. There's been no move to deport them and they have got nowhere to go at all. (KR1) 
Destitution remains a real, if largely hidden, problem. A Leeds City Council report notes that only 19 of the 120 Leeds-based asylum seekers whose claims were rejected in 2003 have been removed from the UK. The whereabouts and means of support of the others are not known. (LCC, 2004). One respondent (FM1) who was involved with a Leeds-based $\mathrm{RCO}$ also reported that their organisation had a list of 40 destitute people. Typically, those devoid of access to public welfare were totally reliant on the charity for their day-to-day survival.

Look at me you're looking at a pauper ... let me use the word we're scrounging, just scrounging, there is no structure of survival. We are merely existing and I don't know why in the first world people are allowed to go like that... We have been having food from this couple they support us, sometimes other well-wishers just throw you a food parcel... Once or twice I've got a food parcel from St George's Crypt... Things need to change. Its inhuman for this kind of treatment especially for close to one year. (FM18 Section 55 asylum seeker)

\section{Meeting basic needs: a key role for RCOs?}

As forced migrants' rights to public welfare are eroded the voluntary/informal sector is often left to pick up the pieces. The UK government has stated that it wants to expand the welfare role of RCOs in the future provision of support for forced migrants (Zetter and Pearl, 2000). As previously noted, three of the forced migrants we interviewed (two asylum seekers, one with ELR) ran Leeds-based RCOs. In spite of highly constrained personal circumstances, they all devoted substantial amounts of time to supporting other forced migrants. None of their organisations is more than a year old. Each individual is essential for the continuation of their particular RCO, which, without their efforts, would cease to exist. The little funding that is available to them has to be obtained via a system of local competitive tendering.

FM23: We don't have money... I'm living in NASS accommodation that is my office, I have a very small room. They [migrants] call me and we meet there.

Interviewer: And do you get money?

FM22: I've asked [The Community Chest fund] for two lots of funding. The first for a cultural event and they gave us the money... The second one I asked for $£ 5,000$ and they gave us $£ 1,000$ and you can't really do the work you want to do...

A key respondent with responsibility for refugee community development in Leeds was dismayed at the assumption that marginalised communities were somehow expected to step in and offer basic support in instances where formal welfare rights had been removed or diminished

I think it's appalling to rely on RCOs. I think the whole idea of this system was that somehow there would not need to be a lot of provision because everybody's going to be looked after by RCOs informally... [Present policy assumes] let the community take care of everybody on the basis that nobody will be just lying on the street, or freezing from cold. We are reverting back to a draconian system where people don't have any rights, especially asylum seekers. (KR3)

The existence of many RCOs remains precarious. Their contingent and informal nature (Kelly, 2003) and limited funding indicate that many are ill equipped to take on a greater role in meeting basic welfare needs (Zetter and Pearl, 2004, 2000). 


\section{Housing issues}

Several issues arose in relation to forced migrants and housing. Concerns about the adequacy and standard of accommodation were evident. Only one of the seven asylum seekers accommodated by NASS contractors at time of interview deemed provision to be more than adequate. Others were more critical.

My house was very bad [it] had four floors ... and I was pregnant so it was difficult for me ... It was very, very dirty ... for three months I fell down the stairs ... we had bedbugs in our bedroom. (FM13 asylum seeker)

The most damming tale was related by an asylum seeker who (legally) worked for a private provider contracted to NASS in Leeds.

One family, a lady with two babies... her house was leaking from the toilet. The carpets were very bad, they were torn everywhere. The sofas were in very, very bad condition, believe me if you threw it away nobody would take it... The kitchen was leaking water, the wallpaper all came off from the lounge because of the water. The water was coming down, she had TV, it was coming on top of the [electricity] sockets ... it was very dangerous. I took it to NASS five or six times about this family and nothing really happened... [finally] The ceiling came down on the floor and then they changed her house. (FM19 asylum seeker)

Leaving aside the issue of standards, a successful claim for asylum generates its own problems. NASS allows a transition period of 28 days for those who attain refugee status to find alternative accommodation. Several key respondents reported that, due to a lack of co-ordination, many successful asylum applicants in reality only get around seven days notice to quit NASS housing. Finding new accommodation in such a short time is often impossible and four of our 11 respondents with refugee or humanitarian leave status either remained in NASS hostels or turned down hostel accommodation to sleep on friends floors before finding a new home. Several others are also currently awaiting further, subsequent, moves into more suitable accommodation. Given the demand for social rented property in Leeds, such hidden homelessness among those with positive asylum decisions remains an issue. In 2003 Leeds Council received a total of 337 applications from people who recorded their cause of homelessness as being a refugee. In the same year 276 applications for re-housing were received from refugees (LCC, 2004).

\section{Housing: reliance on other forced migrants}

The research illustrates that hidden homelessness is also widespread among those who have no right to apply to be housed. All five of the failed asylum seeker/'overstayers' and our Section 55 respondent were effectively homeless and reliant on other forced migrants to meet their housing needs. Those who work (either legally or illegally), rent rooms from 'friends' on a short-term basis. Such friendships are often the result of a chance recognition in the street of a fellow national, and informal short-term accommodation arrangements then ensue. Accommodation is routinely offered for free, but sometimes there is a distinct economic dimension. FM12 (below) was paying $£ 40$ per week plus bills for a room with a refugee who had secured social rented accommodation costing $£ 45$ a week rent.

You can't go to the city council or somewhere else and tell them I need a house, you have to live in somebody else's house. Especially me because my 'friend' he got a city council house. 
I live in his house and I have to pay more because they know I can't find another house, that's why they're pushing me to pay more. (FM12 failed asylum seeker/'overstayer')

Apart from overnight emergency accommodation provided by various housing charities those without the ability to pay rent are totally reliant on the altruism of other forced migrants. Such provision is insecure and places great strain on both provider and recipient.

So it's extremely difficult but if you don't have other options you just go by what is there, whether it's good for you or not... It's a 3 bedroom house, it's them, their daughter and us, but sooner or later next week they will be having another baby and if nothing has changed by then I will probably be on the streets (FM 18 Section 55 asylum seeker).

\section{Conclusion}

Two linked themes are central to policy initiated in response to increased numbers applying for asylum in the past decade. First, is a purposeful attempt to use immigration and asylum legislation to deter those fleeing persecution from seeking asylum in the UK. Second, is a continuing reduction of the welfare rights that are available to those forced migrants who manage to enter the UK. The establishment of the separate and highly conditional NASS system of limited welfare support represents a concerted effort to exclude forced migrants from mainstream welfare services which are to be 'reserved' for citizens. Successive UK governments, ably assisted by sections of the populist press (Statham, 2003), have constructed many forced migrants, as 'undeserving' economic immigrants who have made no prior contribution to their host state and who should, therefore, expect little collective support in return.

Discussions throughout this paper have highlighted the negative impact of this deliberately divisive approach to welfare provision. The creation of a distinct and restrictive welfare system for asylum seekers also has consequences for providers of services. Cohen (2002a, b) argues that by cooperating with NASS and dispersal policy, local authorities and non-governmental organisations have colluded with central government in establishing and administering a coercive and essentially racist system of welfare for forced migrants. In short, such agencies have compromised their independence and capacity for criticising government policy.

The Leeds study provides strong evidence to suggest that statutory provisions are failing to meet the basic housing and financial needs of many forced migrants (cf. CAB, 2002; Eagle et al., 2002; Penrose, 2002). As the responsibility of the state in meeting basic needs diminishes, and the ability of many forced migrants to do paid work is curtailed, the role of informal welfare agencies such as charities, churches and RCOs assume greater importance (cf. Bloch and Schuster, 2002). Furthermore, increasingly the burden of providing basic welfare for those who have no recourse to public provision (i.e. those denied under section 55 and failed asylum seekers/'overstayers') is now being borne by other forced migrants. Forced migrants, who are themselves impoverished, are trying to ensure that the essential housing and financial needs of their less fortunate contemporaries are met. It should be noted that the findings outlined in this paper are not peculiar to Leeds. Many are replicated in other studies that look at the welfare of forced migrants within the Yorkshire and Humberside region (Graig et al., 2004a, b), across the UK (Refugee Council, 2004a) and further a field (Robinson et al., 2003, Edgar et al., 2004). 


\section{Notes}

This research is supported by the ESRC under grant number 000-22-0377.

1 The term forced migrant is used as a general category to include the four groups discussed in the paper. It is recognised that other groups, e.g. those displaced by development projects and people trafficked illegally for exploitative purposes are also forced migrants (cf. Castles, 2003).

2 Space limits a fuller discussion of methods here. Interested readers are referred to http://www. leeds.ac.uk/sociology/people/pddocs/ where details of respondents interviewed, questioning frames etc. are offered in the ESRC end of award report.

\section{References}

Asylum Newsletter (2005), 'Statistics section', Asylum newsletter, Issue 26 March/April, Leeds, Yorkshire and Humberside Consortium/Refugee Council, available at http://www.refugeeaccess.info/uploads/ news/april05.pdf

Bloch, A. (2000), 'Refugee settlement in Britain: the impact of policy on participation', Journal of Ethnic and Migration Studies, 26, 1, 75-88.

Bloch, A. (2004), 'Survey research with refugees: a methodological perspective', Policy Studies, 25, 2, 139-151.

Bloch, A. and Schuster, L. (2002), 'Asylum and welfare: contemporary debates', Critical Social Policy, 22, 3, 393-413.

Blunkett, D. (2001), 'Measures announced to improve immigration control', Press Release 214/01, Immigration and nationality Directorate, Home Office, London.

CAB (2002), Distant Voices: Asylum Support Remains in Chaos, London, Citizens Advice Bureau.

CAB (2004), 'Asylum support' (Amendment) (No. 2), Regulations (2004), Briefing, May, Citizens Advice Bureau, London.

Castles, S. (2003), 'Towards a sociology of forced migration and social transformation', Sociology, 37, 1, 13-34.

Cohen, S. (2002a), 'Dining with the devil: the 1999 Immigration and Asylum Act and the voluntary sector', in S. Cohen, B. Humphries and E. Mynott (Eds.), From Immigration Controls to Welfare Controls, London: Routledge, pp. 141-156.

Cohen, S. (2002b), 'The local state of immigration controls', Critical Social Policy, 22, 3, 518-543.

CPAG (2002), 'Migration and social security handbook', Child Poverty Action Group, London.

Craig, G., Dawson, A., Hutton, S., Roberts, N., and Wilkinson, M. (2004a), 'Local impacts of international migration: the information base', social policy working paper, University of Hull, Hull.

Craig, G., Dawson, A., Kilkey, M., and Martin, G. (2004b), 'A safe place to be? The quality of life of asylum seekers in Sheffield and Wakefield, Hull', Working Papers in Social Sciences and Policy, University of Hull.

Dwyer, P. (2000), Welfare Rights and Responsibilities, Bristol: Policy Press.

Dwyer, P. (2004a), Understanding Social Citizenship: Themes and Perspectives for Policy and Practice, Bristol: Policy Press/SPA.

Dwyer, P. (2004b), 'Creeping conditionality in the UK: from welfare rights to conditional entitlements', Canadian Journal of Sociology, 29, 2, 265-287.

Eagle, A., Duff, L., Tah, C., and Smith, N. (2002), 'Asylum seekers' experience of the voucher scheme in the UK- fieldwork report', Home Office, London.

Edgar, B., Doherty, J., and Meert, H. (2004), Immigration and Homelessness in Europe, Bristol: Policy Press.

GLA (2004), 'Destitution by design: withdrawal of support from in-country asylum applicants: an impact assessment for London', Greater London Authority, London.

Home Office (2003), 'Final phase of asylum reform will build on progress in halving claims', Press Release 326/2003, 27/11/03, London. 
Home Office (2005), 'Asylum statistics 4th quarter 2004', London.

IAP (2004), 'The impact of Section 55 on the Inter-Agency Partnership and the asylum seekers it supports', London, Inter Agency Partnership available at: http://www.refugeecouncil.org.uk/ downloads/rc_reports/iap_s55_feb04.pdf

Kelly, L. (2003), 'Bosnian refugees in Britain: questioning community', Sociology, 37, 1, 35-50.

LCC (2004), 'Report of Scrutiny Board (Neighbourhoods and Housing): Asylum Seekers', May, Leeds City Council.

Mason, J. (2002), Qualitative Researching, London: Sage.

Morris, L. (2002), 'Britain's asylum and immigration regime: the shifting contours of rights', Journal of Ethnic and Migration Studies, 28, 3, 409-425.

Mynott, E. (2000), 'Analysing the creation of apartheid for asylum seekers', Community, Work and Family, 3, 3, 311-331.

Mynott, E. (2002), 'From a shambles to a new apartheid: local authorities, dispersal and the struggle to defend asylum seekers', in S. Cohen, B. Humphries and E. Mynott (Eds.), From Immigration Controls to Welfare Controls, London: Routledge, pp. 106-125.

Penrose, J. (2002), 'Poverty and asylum in the UK', Oxfam/Refugee Council, London.

RCC (2003), 'Clause 8, failed asylum seekers withdrawal of support', Refugee Children's Consortium, London.

Refugee Council (2002a), 'Government announcement and proposals since its white paper on asylum: a summary', Briefing July (2002), London.

Refugee Council (2002b), 'Help and support: hard cases support', Briefing November (2002), London.

Refugee Council (2002c), 'The Nationality, Immigration and Asylum Act 2002: changes to the asylum system in the UK', Briefing December (2002), London.

Refugee Council (2003), 'The refugee council's response to new legislative proposals on asylum reform', London.

Refugee Council (2004a), 'Hungry and homeless: the impact of the withdrawal of state support on asylum seekers', Refugee Communities and the Voluntary Sector, London.

Refugee Council (2004b), 'Asylum seekers win back their rights to basic food and shelter', Press Releases, 25 June, London.

Ritchie, J., Spencer, L., and O'Connor, W. (2003), 'Carrying out qualitative analysis', in Ritchie, J. and Lewis, J. (Eds.), Qualitative Research Practice, London: Sage, pp. 219-263.

Robinson, V. (2002), 'Doing research with refugees and asylum seekers', Swansea Geographer, 37, 61-67.

Robinson, V., Andersson, R., and Musterd, S. (2003), Spreading the Burden? A Review of Policies to Disperse Asylum Seekers and Refugees, Bristol: Policy Press.

Sales, R. (2002), 'The deserving and the undeserving? Refugees, asylum seekers and welfare in Britain', Critical Social Policy, 22, 3, 456-478.

Shelter (2003), 'Voluntary sector unites against new asylum law', Press Briefing, London.

Statham, P. (2003), 'Understanding-anti asylum rhetoric: restrictive politics or racist publics?', in S. Spencer (Ed.) The Politics of Migration: Managing Opportunity, Conflict and Change, London, Blackwell, pp. 163-177.

Travis, A. (2004), 'Blunkett backs down on aid for asylum seekers', The Guardian, 26 June 2004.

Vincent, J. (1991), Poor Citizens - the State and the Poor in the Twentieth Century, London: Longman.

Williams, F. (1989), Social Policy: A Critical Introduction, Cambridge: Polity Press.

Wilson, R. (2001), Dispersed: A Study of Services for Asylum Seekers in West Yorkshire December 1999 March 2001, York: Joseph Rowntree Foundation.

Zetter, R. and Pearl, M. (2000), 'The minority within the minority: refugee community-based organisations in the UK and the impact of restrictionism on asylum-seekers', Journal of Ethnic and Migration Studies, 26, 4, 657-697.

Zetter, R. and Pearl, M. (2004), 'Refugee community organisations', Inexile, 34, 11-12. 